\title{
汽水湖東郷池における 非接触クロロフィル推定手法の検証
}

\author{
作野 裕司 1 ・前田 晃宏 2 - 宮本 康 2 ・森 明寛 2 ・ \\ 岡本 将揮 2 - 畠山 恵介 3 - 九鬼 貴弘 4 \\ 1正会員 広島大学准教授 大学院工学研究院エネルギー・環境部門 \\ ( 干739-8527 広島県東広島市鏡山 1-4-1) \\ E-mail: sakuno@hiroshima-u.ac.jp \\ 2 鳥取県衛生環境研究所水環境対策チーム \\ （干682-0704 鳥取県東伯郡湯梨浜町南谷 526-1） \\ 3 鳥取県衛生環境研究所大気・地球環境室 \\ （广682-0704 鳥取県東伯郡湯梨浜町南谷 526-1） \\ 4 鳥取県水・大気環境課 \\ （ ( 680-8570 鳥取県鳥取市東町 1-220）
}

\begin{abstract}
本研究の目的は, 鳥取県中央部に位置する汽水湖の東郷池において, 非接触で Chl $a$ を推定する手法を検 証寸ることである。この検証のために 2013 年 5 月から 2015 年 7 月までに取得された 42 個（4 時期）の実 測分光反射率/Chla データセットが取得された. その結果, 「湖山池モデル」 $(672 \mathrm{~nm}$ と $704 \mathrm{~nm}$ の 2 波長 比）では $40 \mu \mathrm{g} \mathrm{L}{ }^{-1}$ 以上の高濃度部で大きな誤差が生じた。この誤差を抑制するために, 水中の生物光学的 な理論に基いた新しい 3 波長モデルを取り入れて，この湖に適した計算式や設定波長について検討した。 最終的には, 適切に波長選択された 3 波長（650 nm, $703 \mathrm{~nm}, 740 \mathrm{~nm}$ ) を使った場合, Chla 推定誤差は「湖 山池法」と比較して約 8\%の大幅な精度向上があった。
\end{abstract}

Key Words : remote sensing, drone, reflectance, chlorophyll- $a$, 3 band model

\section{1. はじめに}

鳥取県中部に位置する東郷池では，湖中心部に温泉が 湧く観光地であるが，近年富栄養化が進行し ${ }^{1)}$ ，シジミ の不漁や赤潮またはアオコによる景観悪化等が問題²と なっている. 山陰地方の東西に並ぶ汽水湖の湖山池，中 海，宾道湖も同様な問題を抱えている．最近では異常気 象 (豪雨や温暖化), 越境大気污染などの影響もうけて, 将来的に汽水湖の水質環境が大きく変動することも予想 される. そのため，これらの湖沼では多角的な視点から のモニタリングが求められている. 特にリモートセンシ ング（RS）による水質モニターは安価で時空間的なモニ タリングが可能な手法として，地元では大きく期待され ている.ただし，現行の衛星では雲の影響や長い観測周 期, 限定的な観測波長等の欠点があり, 定常的なモ二夕 リング利用は難しかった，そこで筆者らは，雲下の低空 からイベント時にも即時観測可能で，近年脚光を浴びて いる自立飛行型ドローンを使ったモニタリング手法を検 討している. その基礎研究として，すでに筆者らはドロ ーン搭載のデジタルカメラによる東郷池の赤潮観測法を
考案し，そのマッピングに成功している゙3. さらに，高 精度の植物プランクトン分布を把握する手法として，ド ローン搭載の多バンド分光計を使って非接触で水質分布 を推定する手法も検討している。これまでの研究で湖山 池において船上からの分光反射率により懸濁物質濃度 （SS）に影響されない非接触クロロフィルa（Chla）推 定式（湖山池法と呼ぶ）を見いだした")。しかし，この 推定式は現時点で湖山池のみでしか検証されていない. そこで，本研究では東郷池において，複数回，船による 実測分光反射率と同期した水質調査を行い，湖山池法の 検証をするともに，東郷池においてより安定した非接触 Chla推定式を検討することを目的とした．また近年の研 究で, 富栄養化水域に適した新しい非接触Chla推定モデ ルがいくつか提案されているため，本研究ではそのよう な新しいモデルの適用可能性についても検討する.

\section{2. 研究の方法}




\section{(1) 調査地域}

東郷池は, 面積 $4.1 \mathrm{~km}^{2}$, 平均水深 $1.8 \mathrm{~m}$, 最大水深 $3.6 \mathrm{~m}$, 貯水量743万方, 滞留時間29日, 流域面積 $49.0 \mathrm{~km}^{2}$, 湖岸 延長 $10 \mathrm{~km}^{5}$ の図-1に示寸ような形状をした汽水湖である. 同湖の流入河川は南西部から埴見川, 羽衣石川, 東郷川, 舎人川の4河川で, 寸べて南域の山地から流入する.一方, 流出河川は, 北部の「橋津川」で, この川の長さは約 $2 \mathrm{~km}$ で日本海に通じており, 潮汐によって海水が遡上し湖内 に流入するため, 同湖の水は汽水となっている. 1996年 度からは流出河川の南端付近に設置された水門によって 塩分調整がされている. また, 東郷池は古くからシジミ を代表とする内水面漁業が盛んである. しかし, 近年, 貧酸素水塊の発生, 栄養塩類の溶出, さらには硫化物の 堆積や硫化水素の発生などの水環境問題が深刻化してい $ろ^{2}$. 特に, これらの問題と密接に関係するアオコや赤 潮の発生は, 内水面漁業に大きな被害を与える要因とな るため, アオコや赤潮の指標となるChlaモニタリングは 同湖にとって特に重要なモニタリングパラメータとなる. 同湖のChlaは齊ら ${ }^{2)} の 2005$ 年の調査では表層・底層ともに 0〜29 $\mu \mathrm{g} \mathrm{L} \mathrm{L}^{-1}$ の範囲で推移し，6，9月で高い值を示した. また, 湖北部で低く, 湖中央部から南部にかけて高い傾 向があると報告されている2).

\section{(2) 現地調査データ}

表-1に示すような4日間，午前9～11時の間に図-1に示 寸東郷池の11の基本測点において，分光反射率・ Chla 縣濁物質量 (SS) データセットの収集を行った. 水面直 上における分光反射率は, 船上からポータブル分光放射 計（EKO社，MS720）を使って，400-900 nmの波長範 囲を1nm間隔で測定した。一方，Chlaは同じ測点におい て表層水をバケツ採水後, UNESCO法に従って実験室

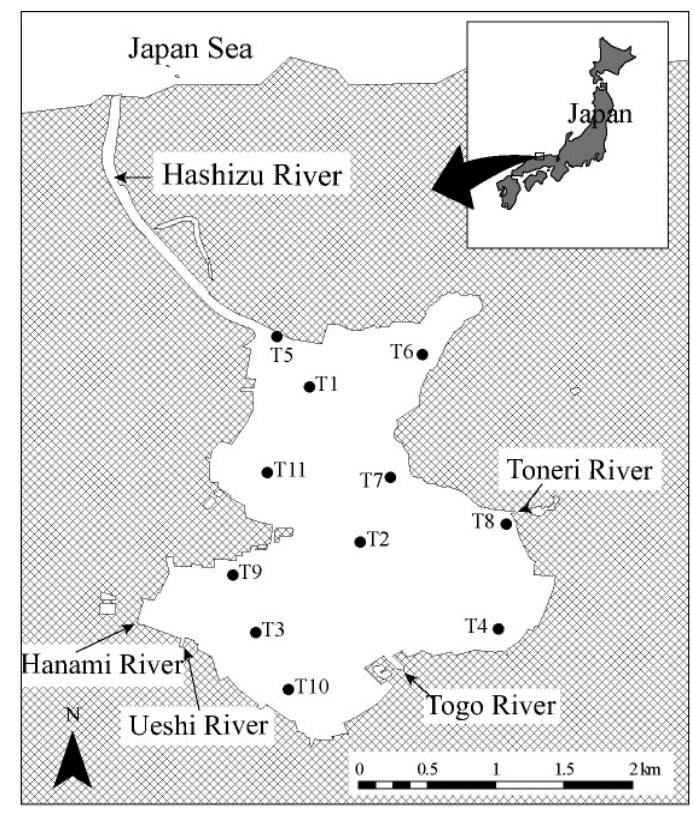

図-1 東郷池の基本測点
表-1 取得された現地の水質データレンジ

\begin{tabular}{cccccc}
\hline & \multicolumn{3}{c}{ Chla $\left(\mu \mathrm{g} \mathrm{L}^{-1}\right)$} & \multicolumn{3}{c}{ SS $\left(\mathrm{mg} \mathrm{L}^{-1}\right)$} \\
Date & Min & Max & Min & Max & N \\
\hline $2013 / 5 / 30$ & 21.5 & 77.2 & 3.6 & 9.6 & 10 \\
$2013 / 8 / 8$ & 6.1 & 60.4 & 4.8 & 12 & 11 \\
$2014 / 3 / 7$ & 81.1 & 145 & 18 & 27 & 11 \\
$2015 / 7 / 21$ & 3.3 & 27.7 & 0.4 & 28 & 10 \\
\hline Total & 3.3 & 145 & 0.4 & 28 & 42 \\
\hline
\end{tabular}

で測定した. 表-1 に取得された Chla と SS のデータレン ジを示す.

\section{(3) 非接触 Chla 推定モデル}

非接触による Chla 推定には, 通常 Chla 吸収の大きい 青バンドと Chla 吸収の小さい緑バンドの反射率比が使 われることが多く, 最も基本的な Chla 推定モデルとして, 以下のような 2 波長モデルによる推定が知られている. 筆者らが湖山池において同様の研究を行った際もこの 2 波長モデルを使用した.

$$
\text { Chla } \propto R\left(\lambda_{i}\right) / R\left(\lambda_{j}\right)
$$

ここで， $R$ は水面上の反射率を示し， $\lambda$ は波長を表す， 実際に使われる 2 波長 $\lambda_{\mathrm{i}}$ と $\lambda_{\mathrm{j}}$ は, 水域によって異なる. 例えば，外洋では「440 nm と550nm」付近，沿岸では $\left\lceil 670 \mathrm{~nm}\right.$ と $720 \mathrm{~nm}$ 付近があげられる ${ }^{6}$. これまで筆者 らが湖山池で見いだした最適 2 波長は「672 nm と $704 \mathrm{~nm} 」$ (土約 $5 \mathrm{~nm}$ ) ${ }^{4)}$ であり, 後者のモデルにあたる. 本研究 では，2 波長を使ったモデルとして，すでに筆者らが見 いだした湖山池のモデルを「湖山池モデル」, 前述した外 洋の代表的なモデルを「モデル A」, 沿岸の代表的なモデ ルを「モデルB」と呼ぶ.

一方，前述した 2 波長の経験的なモデルとは別に，近 年, 水中の生物光学的な理論に裏付けられた半解析的な 3 波長モデル ${ }^{78)}$ の有効性が指摘されている.ここでは, Gitelson $ら^{8)}$ の理論に従って, この 3 波長モデルの説明を 簡単に行う。ここでいう 3 波長モデルとは 2 波長モデル と同様, Chla との関係を以下のような単純な式で表すこ とができる.

$$
\text { Chla } \propto\left[R^{-1}\left(\lambda_{1}\right)-R^{-1}\left(\lambda_{2}\right)\right] \times R\left(\lambda_{3}\right)
$$

ここで $\lambda_{1}, \quad \lambda_{2}, \quad \lambda_{3}$ は，水中の光学特性によって選定さ れる 3 波長を示す.この式の物理的な背景を説明するた め, 水中に溶存する物質の光学的な理論に基づいて反射 
率と水中物質との関係を簡単に解説する．まずは，水面 直上て観測される水面の反射率は以下のような式で表さ れる.

$$
R(\lambda) \propto b_{b}(\lambda) /\left[a(\lambda)+b_{b}(\lambda)\right]
$$

ここで，aと $b_{b}$ はそれぞれ水中物質の吸収係数と散乱係 数である. 非接触による沿岸の Chla 推定において Chla の強い吸収がある青波長では陸域起源の CDOM（有色溶 存有機物）の吸収も大きいため, Chla 推定精度が悪くな る. そこで, 沿岸では CDOM の吸収が比較的小さい赤波 長のChla 吸収を利用することを考える. 赤〜近赤外の特 徵的な 3 つの異なる波長を選んだ場合，式(3)は次のよう にさらに詳しい水中物質の吸収係数と散乱係数で表すこ とができる.

$$
\begin{gathered}
R\left(\lambda_{1}\right) \propto b_{b} /\left(a_{\text {chla }}+a_{\text {cdom }}+a_{\text {tripton }}+a_{\text {water }}+b_{b}\right) \\
R\left(\lambda_{2}\right) \propto b_{b} /\left(a_{\text {cdom }}+a_{\text {tripton }}+a_{\text {water }}+b_{b}\right) \\
R\left(\lambda_{3}\right) \propto b_{b} / a_{\text {water }}
\end{gathered}
$$

ここで, $b_{\mathrm{b}}$ は水中物質の後方散乱係数, $a_{\mathrm{chla}}, a_{\mathrm{cdom}}, a_{\mathrm{tipton}}$ $a_{\text {water }}$ はそれぞれ植物プランクトン, CDOM，無機悉濁物 質, 純水の吸収係数を示寸. また実際に使われる3波長と して $\lambda_{1}$ はChla吸収が青波長に次いで大きい「670 nm付 近」， $\lambda_{2}$ はChla吸収を0と仮定できるまたは無視できるほ ど小さく, CDOMや無機懸濁物質の吸収係数が $\lambda_{1}$ とほぼ 同じ波長の「710 nm付近」， $\lambda_{3}$ は $a_{\text {water }}$ を除く吸収係数は ほぼ無視できるほど小さいと仮定できる「740 nm付近」 がそれぞれ使われる.これらの吸収係数の分光特性と選 択波長の位置関係を確認寸るために，図-2に水中物質の 吸収係数の分光特性と3波長モデルの基本波長の位置を 示寸.ただし，この図で使用される吸収係数（*を付した のは比吸光係数）は富栄養化水域の霞ケ浦で行われた Oyama ら おおよびYang ${ }^{90)}$ の研究に使用されている文 献や数式を参考に，筆者が新たに作図したものである. さらに3波長モデルでは, 赤〜近赤外域において, $b_{\mathrm{b}}$ の波 長依存性が小さい（ほぼ同值とみな寸）と仮定すると， 式(4), 式(5)の逆数の差は以下の式で表すことができる.

$\left[R^{-1}\left(\lambda_{1}\right)-R^{-1}\left(\lambda_{2}\right)\right] \propto\left[a_{\text {chla }}\left(\lambda_{1}\right)+a_{\text {water }}\left(\lambda_{1}\right)-a_{\text {water }}\left(\lambda_{2}\right)\right] / b_{b}$

このうち $a_{\text {water }}$ は地点ごとには变化しない係数なので, 式 (7)を式(8)に書き換える.

$$
\left[R^{-1}\left(\lambda_{1}\right)-R^{-1}\left(\lambda_{2}\right)\right] \propto\left[a_{\text {chla }}\left(\lambda_{1}\right)\right] / b_{b}
$$

ここで式(8)の分母の $b_{b}$ も地点ごとに変化するため, 式(8) と式(6)を掛け合わせて $b_{b}$ の影響を打ち消すと，式(2)の 3 波長モデルが完成する. ただし, 式(6)の $a_{\text {water }}$ も地点ごと には変化しない係数であるため，この係数は無視できる と寸る. なお，ここでは「 $\lambda_{1}=670 \mathrm{~nm} 」, 「 \lambda_{2}=710 \mathrm{~nm}$,

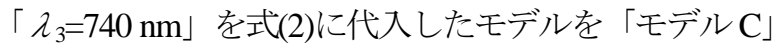
と呼ぶ.

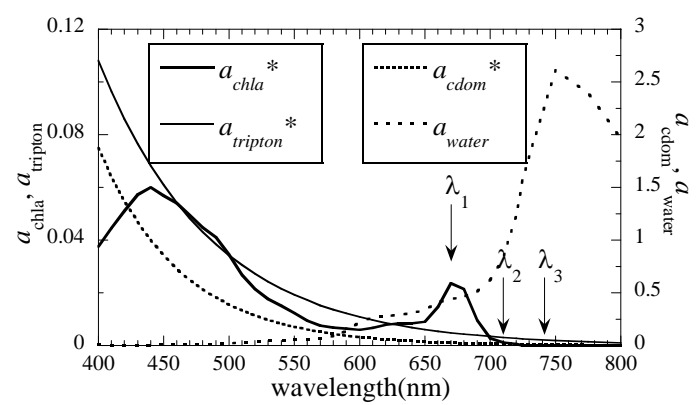

図-2 水中物質の吸収係数の分光特性と 3 波長モデルの基本波 長の位置

\section{3. 結果および考察}

\section{(1) 東郷池の分光特性}

図-3 に東郷池で取得された全分光反射率データの分 光特性を示す（ただし，分光特性を比較しやすくするた めに 700 - $900 \mathrm{~nm}$ の最小值を 0 とするオフセット処理を 行っている). 東郷池の湖水の分光特性は, $570 \mathrm{~nm}$ 付近 に最大值, $750 \mathrm{~nm}$ 付近かそれ以上に最小值, $440 \mathrm{~nm}$ 付 近と $670 \mathrm{~nm}$ 付近に極小を持つ特徴は, 湖山池 ${ }^{4)}$ と同様で 典型的な富栄養化水の分光特性を示している. また図-4 は湖山池の分光特性を示した論文 ${ }^{4)}$ で指摘した，富栄養 化水の Chla 推定に重要な $700 \mathrm{~nm}$ 付近のピーク波長を示 しており，東郷池データでも概ね $704 \mathrm{~nm} \pm 5 \mathrm{~nm}$ 付近に 集中していることが分かる.
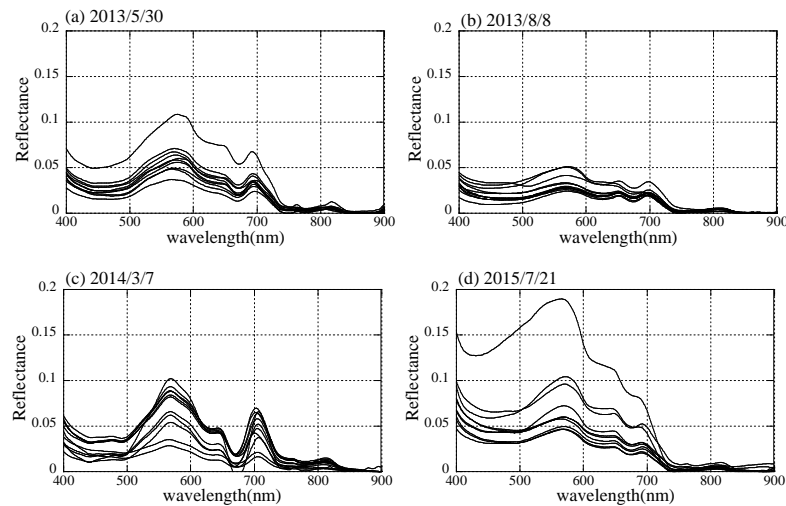

図-3 東郷池の全実測分光反射率特性 


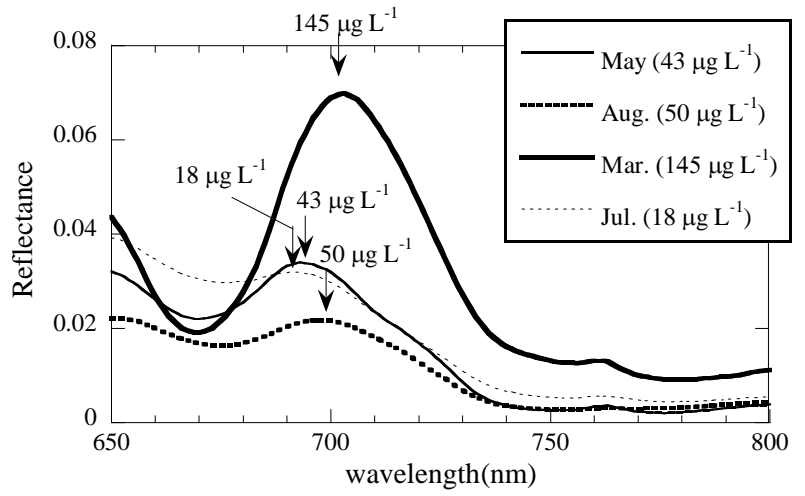

図-4 Chlaによる $700 \mathrm{~nm}$ 付近の波長シフト（いずれも T2 測 点)

\section{（2） 2 波長モデルと 3 波長モデルの検証}

図-5 は, 湖山池法を適用した場合の東郷池の実測 Chla と推定 Chla の関係を示した図である.この図から両者は 概ね一致しているが, Chla が $40 \mu \mathrm{g} \mathrm{L}{ }^{-1}$ 以上になると, 誤 差が大きくなることがわかる．また図-6 は，モデル A, モデル B， モデル C を使った Chla 推定モデルを適用し た東郷池の実測 Chla と推定 Chla の関係を示す．典型的 な 2 波長を使ったモデル $\mathrm{A}$ ，モデル B， 3 波長を使った モデル C を比較したところ，モデル C で比較的大きな 精度向上が確認できた。 なお，本論文における精度の指 標は「相対平均二乗誤差 (Relative Root Mean Square Error : RRMSE)」で表し，この場合，少なくとも 17\%以上の精 度向上があった. ただし，この 3 波長モデルに関する既 往の研究において, 非常に富栄養化が進んだ水環境下

（Chla が 107〜3000 $\mu \mathrm{g} \mathrm{L} \mathrm{L}^{-1}$, 濁度が 11～423 NTU) では, $\lambda_{1}$ は $670 \mathrm{~nm}$ 付近ではなく, $650 \mathrm{~nm}$ 付近が最適であった という報告がされている ${ }^{11)}$. 特に前者のシフトは，植物 プランクトンの種類による誤差 ${ }^{12)}$ を回避することができ ると考えられる．また，その時の $\lambda_{2}$ は図-4 に示される ような，反射率の極大ピーク付近の波長を使っている. そこで，本研究ではモデルC で使われた 3 波長モデルに 従って，東郷池で最適な波長（具体的には「670 nm」を $\lceil 650 \mathrm{~nm}$ に，「710 nm」を「703 nm」）に置き換えた. そして新たに波長を変更したこの 3 波長モデル(「モデル D」と呼ぶ) と実測 Chla の関係を図-7に示す.これより, 東郷池の Chla 精度は表-2 に示すように, 湖山池法と比 べRRMSE で約 6\%の精度向上があり, $40 \mu \mathrm{g} \mathrm{L}^{-1}$ 以上高濃 度部の誤差も大きく抑制された。 なお表-2 には参考值と して平均二乗䛊差（Root Mean Square Error: RMSE）も同 時表記した. モデル D による最終的な非接触 Chla 推定 式は以下のように表される.

$$
\text { Chla }=396\left[R^{-1}(650)-R^{-1}(703)\right] \times[R(740)]+54.1
$$

土木学会論文集B3 (海洋開発), Vol. 72, No. 2, I_964-I_969, 2016.

しかしながら，この推定式を使った場合，図-7に見られ るように, Chla が $100 \mu \mathrm{g} \mathrm{L}^{-1}$ 以上の高濃度は依然誤差が 大きく，改良の余地が残された.

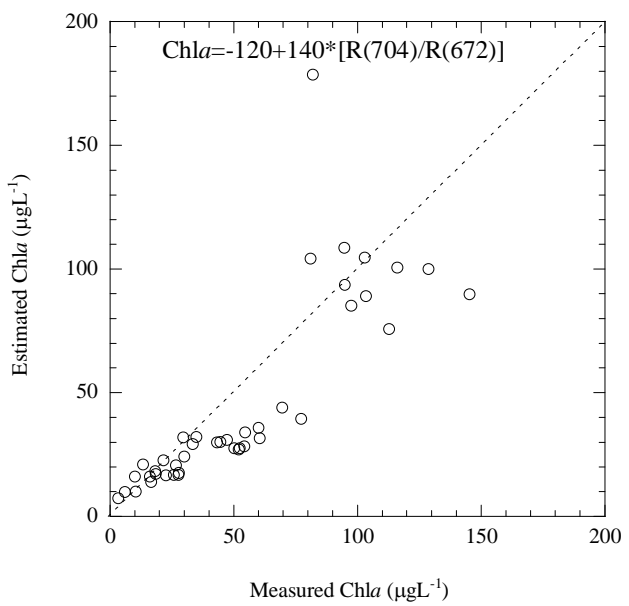

図-5 湖山池法を適用した場合の東郷池の実測 Chl $a$ と推定 Chla の関係

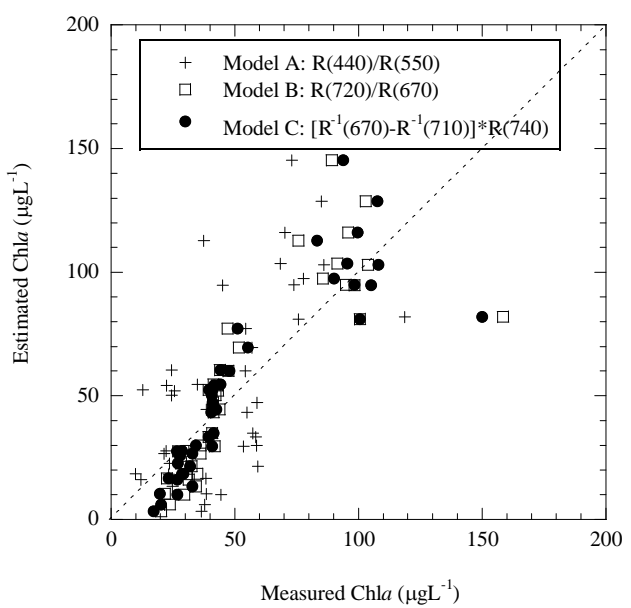

図-6 既往研究モデルを適用した東郷池の実測 Chla と推定 Chlaの関係

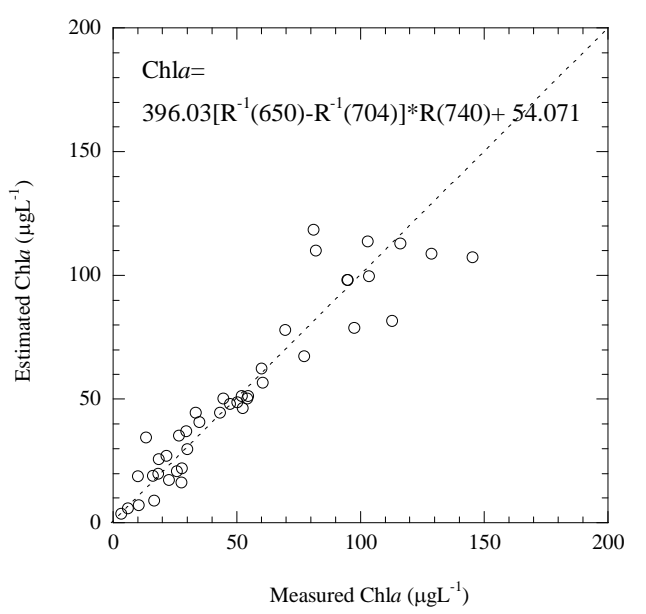

図-7 モデル D を適用した場合の東郷池の実測 Chla と推定 Chlaの関係 
表-2 モデルによるChla 推定精度比較

\begin{tabular}{ccccc}
\hline & Model & $\mathrm{r}^{2}$ & $\begin{array}{c}\text { RMSE } \\
\left(\mu \mathrm{g} \mathrm{L}^{-1}\right)\end{array}$ & $\begin{array}{c}\text { RRMSE } \\
(\%)\end{array}$ \\
\hline 1 & Koyama-ike & - & 22.5 & 40.8 \\
2 & Model A $^{6)}$ & 0.38 & 29.1 & 190.1 \\
3 & Model B $^{6)}$ & 0.70 & 20.5 & 100.4 \\
4 & Model C $^{7}$ & 0.76 & 18.1 & 83.0 \\
$\mathbf{5}$ & Model D & 0.87 & 13.0 & 34.5 \\
& (This study) & & & \\
\hline
\end{tabular}

Number of data: 42

\section{(3) 3 波長モデルの改良}

前節で指摘したように, Chla が $100 \mu \mathrm{g} \mathrm{L}^{-1}$ 以上の高濃 度では, モデルDの3 波長モデルでも誤差が大きくなる. この誤差の原因は「式(6)右辺の分母に後方散乱成分 $b_{\mathrm{b}}$ とデトリタスと呼ばれる吸収成分 $\left(a_{\mathrm{d}}\right)$ が無視できない

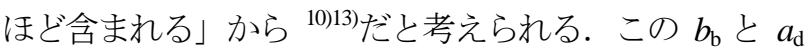
の影響を軽減寸るために, 最近の研究 ${ }^{10)}$ では以下のよう な新たな 3 バンドモデル（ここでは「モデル E」とする） が考案された.

$$
\text { Chla } \propto\left[R^{-1}\left(\lambda_{1}\right)-R^{-1}\left(\lambda_{2}\right)\right] /\left[R^{-1}\left(\lambda_{3}\right)-R^{-1}\left(\lambda_{2}\right)\right]
$$

このモデルは式(2)と基本的な理論に変わりはないが，式 (9)の分母の引き算で, 近赤外域の $b_{\mathrm{b}}$ と $a_{\mathrm{d}}$ の影響を低減 することができる. ただし，ここでも，「 $\lambda_{2}$ と $\lambda_{3}$ の波長 における $a_{\text {cdom }}, a_{\text {tipton, }} a_{\mathrm{d}}$ はほぼ同值とみな寸」という仮 定がおかれている.

図-8 は，モデル E を適用した場合の東郷池の Chla 推 定の検証結果を示している.このうち，(a)はモデル E と 実測 Chla の関係を示しており, 線形よりも 2 次の曲線で よりよい近似 $\left(r^{2}=0.90, \mathrm{RMSE}=11.8 \mu \mathrm{g} \mathrm{L}^{-1}\right)$ が得られた. ここで得られた Chla 推定式は以下の式で表される.

$$
\begin{gathered}
\text { Chla }=54.8+121 x+69.4 x^{2} \\
x=\left[R^{-1}(650)-R^{-1}(703)\right] /\left[R^{-1}(740)-R^{-1}(703)\right]
\end{gathered}
$$

この近似式による Chla 推定は, 表-2 で示される最も推 定精度の高いモデル D よりも，さらに 1.2\%（湖山池法 と比べ約 8\%）の精度向上があった. また式(10), 式(11) を使って推定された Chla と実測 Chla の関係は図-8(b)に 示すとおり, Chla が $100 \mu \mathrm{g} \mathrm{L}^{-1}$ 以上の高濃度でも他のモ デルと比べてばらつきが抑えられていることが確認でき る.
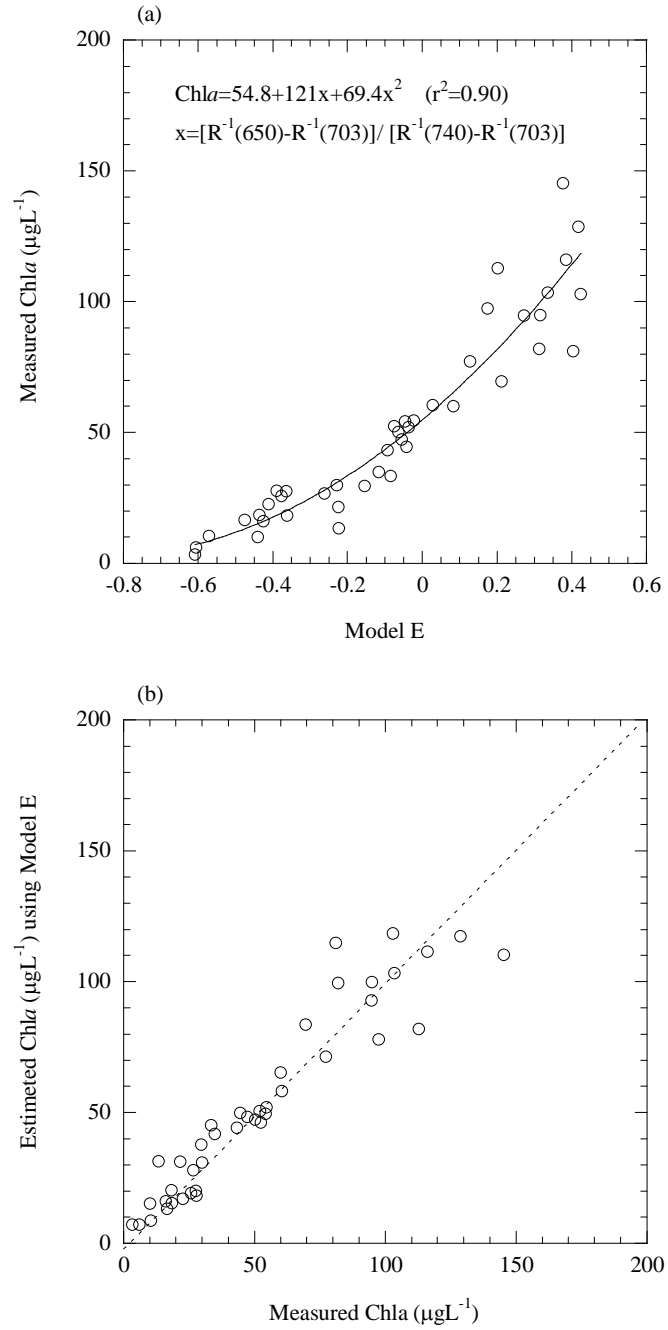

図-8 モデルEを適用した場合の東郷池のChla 推定の検証結果 (a) Model E と実測 Chla の関係，(b) Model E から推定され たChla と実測 Chla の関係

\section{4. まとめ}

本研究では，東郷池で取得された実測分光反射率／ Chla データセットを使って, 非接触 Chla 推定精度の検 証を行った. その結果，「湖山池法」（2 波長モデル）で は $40 \mu \mathrm{g} \mathrm{L}^{-1}$ 以上の高濃度部で大きな誤差が生じた。この 誤差を抑制するために，水中の生物光学的な理論に基づ き，新しい 3 波長モデルの計算式や設定波長について検 討された. 最終的には，適切に波長選択された 3 波長モ デル（モデルE）を使った場合，Chla 推定誤差は「湖山 池法」と比較して約 8\%の大幅な精度向上があった.

今後は, 本研究で得られた非接触 Chla 推定モデルを より多くのデータセットを使って検証する予定である. またドローン搭載した分光計により，より高い高度にお ける非接触 Chl $a$ 推定精度の検証も行いたい. 最終的には, 自動走行したドローンから，アオコや赤潮などの詳細な 分布を定量的にマッピングするシステムを構築したい. 
謝辞: 本研究は, 科研費 (課題番号:15K14041, 25281054), および環境研究総合推進費，新規戦略型課題（S-9）「ア ジア規模での生物多様性観測・評価・予測に関する総合 的研究」（研究代表，矢原徹一）の成果の一部である. 関 係者各位に謝辞を表す。

\section{参考文献}

1) 南條吉之, 福田明彦, 矢木修身, 福井由彦: 汽水湖沼 におけるアオコおよび赤潮発生の抑制に関する基礎 的研究, 水環境学会誌, 第 21 巻, 第 8 号, pp.530-535, 1998.

2) 齊幸治，原田昌佳，吉田勲，平松和昭，森牧人：鳥取 県東郷池における水質の季節的変化と分布特性，農業 土木学会論文集，No.247，pp.31-36，2007.

3) 前田晃宏，宮本康，森明寬，岡本将揮，九鬼貴弘，作野 裕司：UAVを利用した汽水湖沼の実用的な赤潮観測の事 例，日本リモートセンシング学会誌，第 36 巻，第 2 号, pp.126-129, 2016.

4) 作野裕司，畠山恵介，宮本康，初田亜希子，森明寛， 九鬼貴弘 : 汽水化直後の湖山池湖水の分光反射率特性 と水質との関係，土木学会論文集 B3 (海洋開発)，第 69 巻，第 2 号，pp.I_551-I_556, 2013.

5) (財)河川環境管理財団, 河川環境総合研究所 : 我が国 湖沼での沈水植物の再生及び利活用に関する資料集, 河川環境総合研究所資料，第 30 号，2011.

6) Gitelson A. A., Schallesb,J. F., and Hladikc, C. M. : Remote chlorophyll-a retrieval in turbid, productive estuaries: Chesapeake Bay case study, Remote Sensing of Environ- ment, Vol.109, pp.464-472, 2007.

7) Dall'Olmo, G. and Gitelson, A.A. : Effect of bio-optical parameter variability on the remote estimation of chlorophyll-a concentration in turbid productive waters: experimental results. Applied optics, Vol.44, No.3, pp.412-422, 2005.

8) Gitelson, A.A., Dall'Olmo, G., Moses, W., Rundquist, D.C., Barrow, T., Fisher, T.R., Gurlin, D. and Holz, J. : A simple semi-analytical model for remote estimation of chlorophyll-a in turbid waters: Validation. Remote sensing of environment, Vol. 112, pp.3582-3593, 2008.

9) Oyama, Y., Matsushita, B., Fukushima, T., Matsushige, K. and Imai, A. : Application of spectral decomposition algorithm for mapping water quality in a turbid lake (Lake Kasumigaura, Japan) from Landsat TM data. ISPRS Journal of Photogrammetry and Remote sensing, Vol.64, No.1, pp.73-85, 2009.

10) Yang, W., Matsushita, B., Chen, J., Fukushima, T. and Ma, R. An enhanced three-band index for estimating chlorophyll-a in turbid case-II waters: case studies of Lake Kasumigaura, Japan, and Lake Dianchi, China, Geoscience and Remote Sensing Letters, IEEE, Vol. 7, No.4, pp.655-659, 2010.

11) Zimba, P.V. and Gitelson, A. : Remote estimation of chlorophyll concentration in hyper-eutrophic aquatic systems: Model tuning and accuracy optimization, Aquaculture , 256(1), 272-286, 2006.

12）福島武彦，松下文経 : 東アジア湖沼水質モニタリング，水 環境学会誌，第 35 巻，第 2 号，pp.43-47， 2012.

13) Le, C., Li, Y., Zha, Y., Sun, D., Huang, C. and Lu, H. : A four-band semi-analytical model for estimating chlorophyll a in highly turbid lakes: The case of Taihu Lake, China. Remote sensing of environment, Vol.113, No.6, pp.1175-1182, 2009.

(2016.2.4 受付)

\title{
VALIDATION OF REMOTELY SENSED CHLOROPHYLL ESTIMTION MODEL IN BRACKISH LAKE TOGO-IKE
}

\author{
Yuji SAKUNO, Akihiro MAEDA, Yasushi MIYAMOTO, Akihiro MORI, \\ Masaki OKAMOTO, Keisuke HATAKEYAMA, and Takahiro KUKI
}

The objective of this study is to validate the method of chlorophyll-a (Chla) estimation in the brackish Lake Tougou-ike which is located in the central part of Tottori Prefecture. The 42 (4 times) in-situ spectral reflectance / Chla data set was acquired from May, 2013 to July, 2015 for the validation. As a result, a substantial margin of error at the high Chla area of more than $40 \mu \mathrm{gL}^{-1}$ was observed using "Koyama-ike model" using 2 bands of $672 \mathrm{~nm}$ and 704nm. A new three band model based on bio-optical theory in the water was adopted and an optimal expression and suitable bands for this lake were discussed to reduce the error. Finally the Chla estimation model using 3 band model of 650nm, 703nm, and 740nm substantially improved the precision of about $8 \%$ compared with Lake Koyama-ike model. 